\title{
6 ERC Advanced Grant “Lived Ancient Religion”
}

\section{Janico Albrecht}

Roman discourse on religious behaviour can mostly be understood to centre on a negotiation of normative boundaries: In a religion not fixed on a set of authoritative texts, societal processes of communication had to occupy an equivalent role instead. These processes comprise efforts to construct, dispute, and affirm definitions of religious deviance (and norms) without necessarily relying on religious specialists or theological modes of discourse. Quite the contrary, they were based on the medium of narratives about famous individuals' exemplarity or deviance - the two often being interchangeable depending on the context and the target audience. It was a singular characteristic of the Roman Republic that these so-called 'construction-processes of deviance' were extensively tied to the social standing of those participating in them, namely, members of the senatorial elite. For them, taking part in those processes not only required a firm grasp of the often complicated and even conflicting mental outlooks on religious normativity. Furthermore, they were expected, to a certain degree, to 'live up to expectations' by embodying the values of their idealized communities.

This project is centred on these agents who as 'moral entrepreneurs' (Howard Becker) try to assert individual or group interests and claim authority over definitions of right and wrong. Focusing on such figures allows for further in-sights into the society: Who formulates norms, who may formulate norms, and what structural conditions were necessary in an elite keen to ensure its idea of consensus? Building upon a central assumption within the 'Sociology of Deviance' that changes to the normative boundaries of a society need not bear any correlation to the effective behaviour of deviants, the deviant agents themselves will play only a subordinate role. Instead the focus lies on processes of social stratification, strategies of identification, and the appropriation of religious roles.

My approach to the question begins by asking whether the emergence of discourses on individual religious deviance can be linked to the increased acuteness of inner-senatorial competition in the Middle Republican period and the resulting appropriation of religious modes of self-profiling. Historical agents who, at that time, led the way could - as exemplary figures - become fuel for the arguments of later generations as well as authoritative reference-points within such disputes. Late Republican and early Imperial successors (e.g. Cicero, Livy) used references to such earlier discourses, their content, and established results as a medium for anchoring an (imagined) normative senatorial cosmos. These well attested discourses represent the central sources, which can be used to track operative modes of deviance and their relationship to many of those 'moral entrepreneurs', several of whom also influenced the fate of the res publica as political authorities. At the same time, their often high 
degree of literary reflection on the emergence of religious normativity allows consideration of the likelihood that the authors themselves were influenced by and/or able to express constructionist interpretations of their own religious past and present.

In the second part of the project, I consider the way in which the domestic political and external changes wrought by the Principate of Augustus resulted in a shift of debates as well as a change of rules in the game of deviance construction. The original fronts of normative religious definitions became increasingly blurred, allowing for new actors, strategies, and areas of application for definitions of deviance. By including further exemplary cases, a more comprehensive picture will be drawn, which can be linked to the detectable change and changeability of Imperial Roman religion.

\section{Marlis Arnhold}

As member of the ERC-Research Group “Lived Ancient Religion: Questioning 'cults' and 'polis religion"” from June 2012 till May 2013 I started a research project on the sanctuaries of Roman Imperial Ostia, the harbour town of the city of Rome. The project aims for an analysis of the available material and written evidence of the cultsites beyond their differentiation according to architectural forms, cult identities, and their status as sacra private or sacra publica. All of these present criteria based on which the sites have been selected for investigations so far. In view of the program of the ERC-project the idea was to bring together in one study all sanctuaries which a contemporary of Roman Imperial times at least theoretically could have been able to see, know of, visit as well as live or work in or nearby (the phrasing is intended). Focusing thus on the various agents, a number of new questions have been raised for the analysis which result in a fundamentally new understanding of sacred space in Roman Antiquity: How was urban space shared and acquired in and through sanctuaries in Roman Imperial Ostia? Under which conditions was it even competed for? How was it conceptualized and transformed in consequence over time?

My research started with a compilation of the available evidence of the more than 80 known sanctuaries from Ostia from the period of the first four centuries CE. These comprise precincts with large podium temples as well as cult-rooms installed into domestic architectures and workshops but could also take the form of small shrines set into the corner of a courtyard or a niche placed into a wall. They were dedicated to all kinds of religious traditions known throughout Roman Imperial times including the Jewish and Christian cults. Taking into account the aspects of accessibility and visibility, the building phases of the known structures as well as the actions which once took place in and at the architectures were and are being analyzed. Indices for the latter can be obtained from the available finds and inscriptions, in particular, as well as a discussion of the possibilities provided by the available space in each case.

The research on this part of the project quickly resulted in a vast amount of material demonstrating the potentials of the changed perspective on the sanctuaries. All 
the same, further questions arose within the progressing studies, for instance, first of all the one of a terminology applicable to varying architectural forms which allows to address the structures precisely. Whereas some of the larger sanctuaries with Republican history were linked through the activities of various gentes, also "smaller" sites revealed links by means of the preserved inscriptions, which require further discussion of their character: Are we talking just about the presence of members of the same gens in different sanctuaries or were these connected in further ways?

What originally was intended not to exceed the length of a larger essay, soon took the scale of a monography and even though its outline and scope are set, it is still far from finished. Nevertheless, several of the sanctuaries and aspects of this project have already been subjects of recent oral presentations and several articles are in progress of publication or preparation.

\section{Christopher Degelmann}

Scenes of mourning and pleading were omnipresent in ancient Rome. Our sources are full of passages in which burials are described with their specific gestures and signs. The rich archaeological tradition testifies to the importance that death and related ceremonies had in the life of the ancient Romans. In recent years research has devoted countless historical and archaeological publications to the subject.

Nevertheless, the ancient records show a wide range of cases where mourning and supplications are not directly related to death and burial. For example, senators wore mourning dresses in the curia to express their opposition to certain decisions and laws. As private individuals, they walked around the forum in mourning robes and asked the people to vote in their favour at the next meeting. Plaintiff and defendant could use signs of mourning in court to win over the jury. The defendants were even expected to behave in this way and it was a scandal if one of them refused to do so. This is only a selection of different fields of action in which mourning signs and gestures were combined with ritualized pleading, but it is already apparent that the use of semantics of death and burial were options for political strategies in the res publica.

My research focuses on the questions of how and why such signs and gestures worked or when they missed their target. It can be assumed that the scenes described in the sources so often promised success because they contained semantics that were familiar to the Romans from other settings of their everyday life. It is here that the desired emotions usually arose. The analysis of these ancient signs of sorrow and prayer outside their usual contexts assumes that the Roman basic value of pietas, which touched on the fields of family, community and gods, which were elementary for the Romans, was used in particular.

Based on these premises, I hope to not only gain a deeper understanding of a mechanism fundamental to the functioning of the Roman polity, but also to advance 
to the emotional side of Roman politics, far from clichés about instrumentalized religion in the late republic and the early principle.

\section{Valentino Gasparini}

"Small is beautiful". With this provocative title, likely inspired by his mentor Leopold Kohr, the economist Ernst Schumacher intended to criticise the sustainability of Western production systems and propose a human-scaled economic paradigm, thus anticipating several ecological issues with which, almost half a century later, we are still unsuccessfully struggling. Shifting from economics to religious studies, "small is beautiful” encapsulates the methodological approach championed by my project "Lived Ancient Religion (LAR): Questioning 'Cults' and 'Polis Religion””. This project was interested specifically in a "smaller" religion, yet not in the sense of "small gods" (to cite the title of Terry Prat chett's novel), that is, of deities allegedly occupying a lower position within the hierarchy of the Graeco-Roman pantheon. Rather, the study explores "the gods of small things" (citing now Arundhati Roy's novel), that is, the question of how human religiosity is affected by small things and how different local small-scale religious providers and entrepreneurs filtered, appropriated, adapted, instrumentalised or even invented new religious offers. In short, this study does not investigate elements of coherence and homogeneity within an allegedly shared religious worldview, but instead concerns itself with particularities, discrepancies and distortions within situational contexts.

The common topic that ties this project together is the Isiac cults. These are the cults (in the Graeco-Roman world from the beginning of the third century bCE to the beginning of the sixth century $\mathrm{CE}$ ) of a dozen deities conceived of as originally worshipped in Egypt and belonging to the same mythical and liturgical circle: (Herma-) Anubis, Apis, Boubastis, Harpocrates, Horus, Hydreios, Isis, Neilos, Neph thys, Osiris and Serapis. Of course, the selection of the Isiac cults for this enterprise does not aim at reifying these cults as a quasi-religion, that is, as a self-sufficient system of religious belief and practices. Rather, it represents the arbitrary selection (within the wide spectrum of polytheistic options) of a heuristic tool encouraging the analysis of the different strategies by which the religious actors (individuals as well as smaller or larger social groups) built their own cultural idea of "Egypt" and used diverse materials (mediated orally, through texts or iconographies) to capitalise on the symbolic power of "Egypt" by incorporating and "othering" what they found. According to the LAR perspective, my research supports a methodological shift from the idea that the institutionalised civic religion is the dominant structure (based on the static and standardised performance of public, collective rites, and on elite-driven ideology) to a focus on theindividual as an active (often unpredictable) actor, capable of situational and creative innovation. This line of research is interested in the single cultic agents, not as "normalising" actors (that is, representatives of institutional entities or 
local oligarchies) but as individuals who (independently of their social position) act as decision-makers and conscious modifiers of established religious patterns. I provide a different account on the social dimension of Isiac religious practice, including variety, creativity, religious multiplicity, fluidity and flexibility of identities, changes in forms of individuality, and spaces for individual distinction. The Isiac cults can be investigated as a practical resource available to emergent or self-styled religious providers.

\section{Maik Patzelt}

Die vorliegende Dissertation hat sich um einen Quellenzugriff bemüht, der es erlaubt, eine Untersuchung des Betens im spätrepublikanischen und frühkaiserzeitlichen Rom in all seinen Facetten über eine Analyse verfügbarer Gebetstexte hinaus zu bestreiten. Während die bisherigen philologischen und historischen Modelle zur römischen Religion ein Verständnis für die Vielfältigkeit des Betens im antiken Rom verhindern und dieses auf normative und formalisierte Akte reduzieren, die von einem kulturellen oder kultischen Wissen diktiert und mit Hilfe eines schriftlichen Regelwerkes priesterlich verwaltet werden, erhebt die Studie das betende Individuum inmitten des ihn prägenden und umgebenden sozialen Kontextes zum Ausgangspunkt der Untersuchung. Dabei wird das Beten als ganzkörperliche und multidimensionale Kommunikation begriffen. Das Beten ist vor diesem Hintergrund als ein Ausdruck ,gelebter Religion“ erschlossen worden. Im Hinblick auf einen hierfür notwendigen Handlungsbegriff, der in einer Verkörperung gründet, hat sich das Konzept der Ritualisierung als geeignetes Instrument erwiesen, um den individuellen Handlungsmöglichkeiten nachzuspüren. Die theoretische und methodische Herausforderung bestand darin, aus dem herauskristallisierten kreativen Handeln eine religiöse Erfahrung erschließen zu können. Zu diesem Zweck wurde das handlungstheoretische Ritualisierungskonzept mit einer Bandbreite an anthropologischen, psychologischen und kognitionswissenschaftlichen Studien in Verbindung gebracht. Daraus ergab sich ein Schema, das ein stark verfremdetes bis selbstvergessen-exaltiertes Beten in Einheit mit erregenden bis ekstatischen Erfahrungen setzt. Der jeweilige Moment des Handelns evoziert in seiner Komplexität subjektive Erwartungshaltungen, die als eine religiöse Erfahrung oder als eine Erfahrung göttlicher Präsenz wahrgenommen werden können.

Die Untersuchung entlang dieses Schemas hat ergeben, dass dem Beten keine normativen und formalisiert-instruktiven Handlungsmuster innewohnten. Weder ließ sich das Gebet als eine geschlossene Handlungskategorie verifizieren, noch ließ sich die Existenz normativer Schriften in Form von Gebets- oder Ritualbüchern nachweisen. Demgegenüber konnte das kreative Potenzial eines betenden Römers offengelegt werden, der darum bemüht ist, für den jeweiligen Moment ein Gebet sprach- 
lich und körperlich zu ritualisieren. Ausgehend von verschiedenen Faktoren wie Publikum, Lebenssituation, Lebenserfahrung, persönliches Anliegen oder Götterbild etc., eröffnete sich eine nahezu unerschöpfliche Bandbreite, das eigene Beten zu gestalten. Am eindeutigsten ist dies bei den salutationes in römischen Tempeln zu beobachten. Diese hatten zum Ziel, eine persönliche Nähe zu einer Gottheit kommunikativ zu etablieren und zugleich zu erfahren. Eine Bandbreite an Ritualisierungen eröffnete sich etwa bei den Gebeten der Aristokraten, da diese versuchten, den eigenen Auftritt den Erwartungshaltungen eines Publikums anzupassen. Der betende Magistrat wurde vornehmlich kreativ tätig, indem er der priesterlichen Komposition auf lautlicher und körperlicher Ebene Gestalt verlieh. Die beistehenden pontifices vervollkommneten den Auftritt, indem sie dem Magistraten nicht lediglich die textliche Grundlage boten, sondern es ihm in darstellerischer Hinsicht gleichtaten. Ausgehend von diesen Beobachtungen kann ich grundlegende Einblicke in die Vielfalt des Betens im antiken Rom liefern und ein neues Bild religiöser Praxis in Rom entwerfen.

\section{Georgia Petridou}

The three years of research in the project "Lived Ancient Religion" at the Max-WeberKolleg have been a true revelation for me. I learned so much not only about history of religions but also about hard-working ethos and collaborative spirit within academia. My individual research area within the wider LAR project was "Interactions with Religious Specialists”. Working with Jörg Rüpke, Richard Gordon, Rubina Raja, our distinguished research fellows (such as Jan Bremmer, Julia Kindt and Alexia PetsalisDiomidis) and the rest of the LAR team in the field of history of Greek and Roman Religion has been a dream for me that has come true. The wider context of interaction with other specialists in the humanities and the social sciences at the Max-WeberKolleg has also been extremely beneficial for both my project within LAR and my personal development as a researcher. From the first month of my employment I took part in a long series of fascinating academic conferences. The conference that was focused on narratives was a true eyeopener for me, as it related both to my previous work on the divine epiphany and its emplotment in narratives and my current project on Aristides' self-conscious and “tormented" religious narrative, the Hieroi Logoi. In January 2015 I felt particularly privileged to be able to co-organise a three-day international conference on the religious professionals and their role in the cultic cosmos of the Imperial Era with Jörg Rüpke and Richard Gordon. Just before I left the MaxWeber-Kolleg I co-organised a workshop on the materiality of divine agency with Katharina Rieger. One year later I guest-edited a special issue (3.2) of the journal $R e$ ligion in the Roman Empire. The issue is dedicated to embodiment and "lived ancient religion" and is entitled "Embodying Religion". I shared six different papers, all drafts of chapters from my forthcoming monograph on Aristides, with my colleagues at the 
Max-Weber-Kolleg. The feedback I received every step of the way was extremely helpful and constructive. To say that I was very happy working for the LAR project would be an understatement. The Max-Weber-Kolleg inspired me to produce a significant number of research outputs that secured me a permanent Lectureship in Ancient Greek History at the University of Liverpool.

\section{Anna-Katharina Rieger}

Coming to the Max-Weber-Kolleg as an archaeologist was one of the most challenging opportunities along my way in academia. For three and a half years I enjoyed, as member of the project "Lived Ancient Religion", the unique qualities of this highly interdisciplinary and diverse, intellectually ambitious and constructively working place to study, meet and discuss topics in cultural and social studies. Within the frame of the project "Lived Ancient Religion" I dealt with sacred spaces in Roman provinces of Western Asia (today's Syria, Lebanon and Israel). Even though the topographical tailoring encompassed a desk-and-libraryoriented study, it offered even more the opportunity to look freshly onto sacred places which for decades were studied predominantly under aspects of provinciality or Romanness and religious syncretism. To overcome these interpretations, I applied an agent-based as well as a spatial approach that encompassed an investigation of how places are embedded in a larger socio-topographical context. Who invested in what parts of them and why; how places were internally organized and where can "hot spots" of ritual activity be marked off. By overcoming the dichotomies of elite vs. rural religion, provincial vs. Roman styles or nomadic vs. urban contexts, perspectives opened onto the differentiated and differentiating processes of growing and decreasing interest, fame, spatial functionalities and communication according to the people acting in the sacralised places. The agents organising and enlivening the sacred space at Seeia (Southern Syria) cannot be understood without the landscape features, spatial relations and resulting lifestrategies around. A closer look onto the composition of the people, present in the sacred space, indicated the various interests and investments, not only in a rich architecture and dedications, but even more importantly in a complex water management system, covering and religiously imbuing a large territory. Investigating not only individual places but their relations helped pin down religious life in the making, often out of a continuous competition. The situational aspects of religious activities - where, who and when - were studied in roadside shrines along the routes of the Arabian Desert, used by passers-by. Inscriptions, graffiti and imagery revealed the spontaneous formation of the groupings for a religious act. The horizon of experience and expectation shaped the way in which they added their names and dedications in order to perpetuate the communication to their fellow agents. The limitations of discerning "lived religion" due to characteristics of archaeological material are clear-cut. However, the focus on the religious agents and on situational settings and 
contexts of objects, people, texts, reshaping religion and its spaces, lead to new interpretations of seemingly well-known sacred places, and revised the assumption of religion as a pre-set system.

\section{Jörg Rüpke}

The initial formulation of the Lived Ancient Religion project was a proposal about how one might rethink the conceptualisation of the vast, amorphous, heterogeneous body of material that bears upon what is conventionally known as "the religion of the Roman Empire”. The very topic had itself hardly existed before the 1980s, being regularly confused with "ancient Roman religion" on the one hand, and the "Oriental religions of the Roman Empire" on the other. The initiative was grounded in three specific challenges to existing approaches:

(1) we criticised the implicit assumption that all inhabitants of the Empire, from the Republican "empire of booty" to the supposedly christianised empire of Theodosius I in the late 4th century CE, were equally religious (the "homo religiosus" fallacy).

(2) We also questioned the focus upon civic, i.e., collective, institutionalised religious practices. This is vital because that focus produced a series of supplementary subcategories (which are at the same time conceptual strategies), such as "mystery-religions”, “oriental cults”, “indigenous cults”, “votive religion”, “funerary rites”, in order to save the phenomena, yet whose relation to civic practice is quite indeterminate - they are sub-categories that are neither empirically convincing nor analytically adequate.

(3) We criticised the practice of treating "pagan" religion, Judaism and Christianity as though they had existed historically in quite separate worlds - enshrined in a disciplinary division of labour that has been enforced since the rise of Neo-humanism in the late eighteenth century. Against a tradition of scholarship heavily invested in concepts of "tradition" and "sacral law”, Lived Ancient Religion did not reconstruct local ancient religion as an ahistorical set of "symbols" of fixed meaning or from individual experiences ("belief"), but from the historical agents that are the producers of our "sources". It emphasised the social context of action deemed "religious", and specifically the "group-styles" that influence linguistic and behavioural patterns in specific cultural contexts, such as the (non-nuclear) family, neighbourhoods and associations. From this perspective, public cult appears less as a set of ideals that can in practice never be lived up to, but more as a scheme of ordering priorities and distinctions whose effect is to outline (rather than define) an imagined community. Apart from several monographs, many results have been published in issues of Religion in the Roman Empire. An article, co-authored by all members of the team and entitled "Religion in the Making”, has been published in Religion 48 (2018). Proceedings from the final conference at Eisenach will be published in April 2020. 


\section{Benjamin Sippel}

Although numerous generations of ancient historians have rendered outstanding services to the study of the social and religious history of the Roman Empire, many details are still in the dark: What concrete socio-religious developments and constellations, for example, have contributed in the long run to the disappearance of polytheistic cults from a particular village and to Christian cult taking their place? A key to answering this question lies in the consideration of the temple personnel who performed public cult acts and were responsible for the maintenance of the sanctuaries: With these actors, the general cult activity stood and fell.

In my dissertation, I am therefore dealing with the question of which processes of change the Egyptian and Hellenistic rituals experienced in Egypt in the first centuries of Roman rule, which religious topography the spreading Christianity thus found in the rural regions of the country, and which factors favoured the decline of the one religion and the spread of the other, or made it possible at all, at the beginning of the fourth century CE. In this context, I examine the importance of the priestly offices in these persons' way of life and vice versa, the place of the cult functionaries in the village structures, and the extent to which changes in other areas of life affected the performance of their religious duties.

The villages of the Lower Egyptian Fayum Basin offer themselves first of all as a place of investigation, since on the one hand by far the most sources on polytheistic temple personnel come from this area and on the other hand some of the earliest traces of Christian practices and semantics can be found here. Should the work progress faster than planned, other regions of Egypt will be included in the study.

The papyrus fragments preserved from the Roman era offer the opportunity to gain a lively and varied insight into the life of the temple staff. Among other things, private letters, contracts and census declarations tell us about the everyday business, difficulties and life plans of the cult functionaries and document how they came to terms with the events of the day, sometimes resisted and with each of their actions determined anew the direction in which the future of the temple business on the knife edge leaned. Archaeological and epigraphic source material will also be included in the work, thus creating a cross-disciplinary work that brings together the findings of Egyptology, ancient history and religious studies, among others. 